\title{
PRESIDENTS AS PRACTITIONERS: THE LIVED EXPERIENCE(S) OF FORMER STUDENT BODY PRESIDENTS WORKING IN HIGHER EDUCATION, STUDENT AFFAIRS
}

\author{
Michael A. Goodman, University of Maryland-College Park
}

A student body president's work involves addressing emerging crises and challenging institutional decision-makers to respond to the cost of higher education, campus sexual assault, mental health, free speech, and student safety (Student Voice Index, 2018). This phenomenological study unearths the experiences of individuals who previously served as student body president of their institution's student government and who now work in higher education and student affairs. Three themes emerged as a result of multiple interviews with eight former student body presidents, including having a reserved "seat" at "the table," pre-exposure to a career in higher education and student affairs, and a whiplash-like transition following their term. As a result, implications involve the importance of student elections and attention to a retirement-like experience for former student body presidents.

ACCORDING TO THE AMERICAN STUDENT GOVERNMENT ASSOCIATION (n. d.), all education institutions should support student governance organizations and recognize student governance groups as the "student voice" of the campus. Student governments are typically led by a president, or "student body president" (SBP), who engages with students about their concerns, feedback, and campus issues (Miles, 2011). The role of SBP evolved as self-governance increased responsibility and importance (May, 2010). According to the National Campus Leadership Council's (NCLC) Student Voice Index (2018), SBPs address emerging crises and challenge institutional decision-makers to respond to challenges such as the cost of higher education, campus sexual assault, mental health, and balancing free speech and student safety. Additional issues and concerns involve residence hall visitation, funding for clubs and organizations, increasing the number of student organizations, smoking on campus (Miles, 2011), and student fee allocation (May, 2010; Smith et al., 2016).

If institutions for higher education across the United States elect an SBP each year, there becomes no argument that there are a lot of past-SBPs in the workforce today. But it is unknown how many of these individuals pursue careers in higher education or student affairs (HE/SA). While we know a lot about the histories of student government as a functionality of a college campus (Alexander, 1969; Bloland, 1961; Dungan \& Klopf, 1949; Frederick, 1965; Klopf, 1960), and the experiences of new professionals and graduate students in HE/SA (Hall, 2014; Renn \& Hodges, 2007; Tull, Hirt, \& Saunders, 2009), this study illuminates the intersection of those serving specifically as SBP who are now working in HE/SA. Using a phenomenological research approach, I ask the question: What is the lived experience of former Student Body Presidents working in higher education or student affairs? Asking such a question in this broad manner allows for insights to be illuminated as implications while remaining open to what is brought forward by participants.

\section{LITERATURE REVIEW}

Student government survived through generations as a fundamental component of U.S. higher education (May, 2010). The value of student government can be understood through the histories and influence on both the 
student(s) and the institution(s) (Dungan \& Klopf, 1949). In part, students' self-governance arose from dissatisfaction with institutional rules and procedures and a "desire for student empowerment" (May, 2010, p. 208). Student self-governance evolved from early literary societies and appeared in honor systems, assemblies, class councils, student councils, and most recently, student associations (May, 2010). Student associations generally include serving as the voice of the student body to administrators, and overseeing fees, student organizations, and programming (May, 2010; Miles et al., 2008). It is one of many campus activities that enables an understanding and appreciation of cultural and human difference, global perspectives, and civic responsibility (Komives, 2019).

Participation in student government is linked to individual student outcomes and positive contributions to the welfare of the community (Komives, 2019; Kuh \& Lund, 1994). Students involved in college governance receive training and experience that enhances their education and development (Terrell \& Cuyjet, 1994). Such training includes organizing, planning, decision-making, managing, and working with different populations of people (Kuh \& Lund, 1994). As representatives of their constituents, student government leaders can be a resource in forming policy (Terrell \& Cuyjet, 1994). As governance bodies in higher education can be relatively segregated (Miles et al., 2008), campus administrators should decide the responsibilities of students and the level of authority given to them (Klopf, 1960).

Studies on student government reveal a shared governance between students and higher education professionals that afforded acceptability and support for policy decisions (Terrell \& Cuyjet, 1994). Representation often conveys how an institution responds to trustees and leaders, and at times, students are even granted a seat with trustees (Smith et al., 2016). Together, senior student affairs officers and student government leaders can influence policy, practice, and procedures (Golden \& Schwartz, 1994). The togetherness implied in the literature opposes an us-against-them mentality. However, the role that students play depends on the philosophies of the faculty, administration, and any trustees affiliated with the institution (Klopf, 1960). Over time, student self-governance matured alongside other aspects of higher education and solidified as a fundamental part of a college or university campus (May, 2010).

While the research on student government and self-governance remains consistent over time, published research on SBPs, specifically, is sparse. In one study on the experiences of SBPs, Miles (2011) found that SBPs desired structure and procedure but wanted the freedom to break away from campus tradition(s). SBPs worked with faculty or staff members as advisors and interacted with additional staff members and administrators, some of whom also served in unofficial advising capacities (Miles, 2011). Part of serving as an SBP involves meeting with key administrators, maintaining speaking rights in key community spaces (e.g., board meetings), and representing students' voices (Student Voice Index, 2018).

In 2004, Miller and Kraus explored whether women were equally represented in student government leadership roles and found that women were elected mostly as representatives, and much less in President and Vice-president positions. At the time, women held nearly half of the student government positions, whereas men held over $70 \%$ of the President and Vice-president positions (Miller \& Kraus, 2004). In 2020, Workman and colleagues found that women student government presidents endured a "boy's club" that led to a "chilly climate" in their student government experience. Participants described the climate with regard to the organizational culture, bias against women, and challenges inherent to the election and transition process (Workman et al., 2020). In unpublished dissertation work, Mink Salas (2010), Rupert Davis (2019), Spencer (2004), and Zimmerman (2017) all explored women, leadership, and student government experiences (several of which were SBP-focused). Zimmerman (2017) found that social justice, advocacy, and activism prepared many women in her study to run for SBP. Similarly, Rupert Davis (2019) posited that campus diversity and inclusion issues impacted how women engage in leadership roles. While women leaders helped sustain and expand student self-governance, similar to additional underserved populations such as African American, Jewish, and Asian students, limited access to higher education in the U.S. delayed involvement in the first three centuries (May, 2010). For example, it was not until 2000 when a Black student, Nic Lott, was elected SBP at the University of Mississippi (Racial Attitudes of America's Youth, 2000). 
In their study, Miles et al. (2008) found that students agreed most strongly that the ideal characteristic of student government leaders was that they represented all student interests and were willing to communicate with diverse students and advocate for students with administrators. SBPs who meet regularly with the senior student affairs officer feel they have a stronger voice than those who meet less frequently (Student Voice Index, 2018). However, only 55\% of SBPs report feeling very or extremely influential on their campus (Student Voice Index, 2018). Miles (2011) asserted, "Although they serve in leadership roles, student leaders are still students. They are learning skills they will use throughout their personal and professional lives. Struggling with these issues may be part of the student's development" (p. 330). Students put in long hours managing campus events, funds and budgets, and student issues, and assuming the task of the president can often amount to a full-time job (The JBHE Foundation, Inc., 1998). Furthermore, students are challenged by the restraints of term limits, special interests, Greek-letter voting blocks, exhaustion from participation, and turnover (Smith et al., 2016). For example, student governments have significant transition issues when leaders turnover, including losing graduating seniors to be replaced with first-year students (Smith et al., 2016).

\section{METHODOLOGY}

The methodology in this context also serves as a philosophical grounding for human science research (van Manen, 1997). Here, philosophical underpinnings guide this study (Gadamer, 1975; van Manen, 2014). Human science research acknowledges how one orients to lived experience (van Manen, 1997). Human science studies people, and specifically, applied phenomenology in this way is human science research (van Manen, 1997). I rely on philosophers like Hans-George Gadamer and Martin Heidegger to center this study as being in the world (with participants, and alongside participants). I carry into this study my prejudices (as pre-understandings, rather than the pejorative implication the term often carries), and a belief that all knowledge consists of prejudices (Gadamer, 1975). For example, I have experience with undergraduate and graduate student government and $\mathrm{HE} / \mathrm{SA}$ practice. I understand the language associated with each of these functional areas, and am attuned to current events, challenges, and pressing issues. I am an insider with insider knowledge.

Phenomenology is not solely about illuminating lived experience. Many qualitative methodologies suggest such an illumination. Here, there is a call to understand the essence of lived experience. Understanding the essence of a phenomenon - the essence of this lived experience-is the starting and endpoint of phenomenological research (Hultgren, 1995). Phenomenology is an approach that enlists deep interpretation (Gadamer, 1975; van Manen, 2014), and resists that which is fixed in theory (Gadamer, 1975). While qualitative research can greatly inform student affairs practice (Arminio \& Hultgren, 2002), to be grounded in phenomenology is not a series of implications or recommendations. Instead, insights are gleaned based on the themes associated with this phenomenon.

\section{Positionality and "Turning”}

Proper to applied phenomenology and van Manen's (1997) six research activities, a study such as this contains a personal "turning" to the phenomenon. In this way, a "turning" captures how I, the author, "turned to" or discovered this topic as one worth exploring through research. For example, I served as Student Body President my junior year of college. By my senior year, I had developed a connection with the university president that was stronger and more personal than the relationships I had with many of my professors. I had access to numerous calendar-gatekeepers who allowed me to meet frequently and easily with various campus stakeholders, and I even had my university president's cell phone number. The morning of my graduation, I received a text from my parents that they had forgotten to pack their graduation tickets. My parents lived in a different state than my undergraduate institution, and at the time, graduation tickets were highly coveted and (problematically) necessary to gain entrance into commencement. Enlisting the one personal "favor" I had ever asked of him, I texted my university president to see if he could assist. He quickly responded, and within minutes showed up at the back door of the field house to let in my family and several friends.

When I started graduate school two years later, I struggled to find my place, especially on a campus where I felt 
like a tiny minnow in a big ocean, and after having felt like a giant whale in a mid-sized lake. I recall only seeing the university president just two times in-person during the two years of my graduate studies. Each time took place during a ceremonious something-or-other. I have met and conversed with several former SBPs who share similar experiences over the years working in higher education and student affairs. It was my own experience that helped me "turn" to this phenomenon, and the conversations with others that ultimately led to my desire to conduct this study.

\section{Phenomenological Process}

Following IRB approval, a call for participants remained open for three weeks. Eight individuals who met the criteria were selected and volunteered to interview with me about their experience(s). At the time of the interviews, participants in this study all worked in HE/SA as full-time practitioners or graduate student practitioners, and previously served as undergraduate SBP within the three years prior to the commencement of this study (2016-2019). While some participants identified as graduate students, I frame their work as practice beyond their undergraduate experience. Many new professionals gain fundamental and entry-level knowledge and skill development from preparation graduate programs (Kuk \& Cuyjet, 2009), and are primarily socialized into the profession through graduate school (Collins, 2009). Furthermore, honoring graduate student labor is an essential part of my own definitions of student affairs practice.

\section{Data Collection and Data Analysis}

Participants filled out consent forms prior to the first interview, and after the second interview, were invited to identify their own pseudonyms. I conducted two 60-90-minute interviews with each participant via Skype or WebEx, and each individual was provided a \$10 Amazon gift card for their participation. I enlisted semi-structured interviews (Bevan, 2014; Patton, 2002), which were transcribed using Rev transcription services and placed in one major document for review. Consistent with hermeneutic phenomenology, insights were gleaned from an in-depth review of interview transcripts. Interviews were listened to to capture tone and emphasis, and transcripts were read multiple times to capture statements and phrases that were essential to revealing the phenomenon (van Manen, 1997). This process involved first reading the transcripts multiple times. Themes were then created by analyzing data through a selective highlighting approach (van Manen, 1997). This process took place over a period of two months.

\section{Participants}

Abigail is a first-generation college student who grew up in the Midwest. She went to a large public institution for her undergraduate degree, and a private institution in a large city for her master's degree in HE/SA. She served as SBP her senior year, three years before our conversation. Abigail now works in housing at a small private college.

Adam is a doctoral student in the Northeast and achieved a master's degree in HE/SA prior to starting his doctorate. He served as SBP of his small private school in the Southeast during his final year as an undergraduate, and we spoke three years following his serving in that role. He now works in advising and intercultural affairs.

Emily is from the Northeast and served as SBP of her small private institution during her senior year. We spoke one year after her term as president, which was one year into pursuing a graduate degree in student affairs. In her current assistantship, Emily advises students and student organizations.

Gus is from the suburbs of a large Midwest city. He attended a small private institution in the Midwest and served as SBP his senior year. We spoke two years following his term, and after the completion of his master's degree in higher education. Gus now works as an education consultant in a major Eastern coastal city.

Karlie is from the Midwest and went to a small private school in a large city. She served as SBP her senior year, her first and only year to be directly involved in student government. Karlie went to a public institution for graduate school, and we spoke two years after her presidency as she was working in leadership programs at another 
large public institution.

Penny is from a small town in the Midwest and went to a small private institution for her undergraduate degree. Penny served as SBP her senior year of college. She worked for one year before graduate school, and we spoke after her first year of pursuing a master's degree in HE/SA. As part of her assistantship, Penny works in student activities and student organization advising.

Ron grew up in the Northeast and went to a small private institution for his undergraduate degree and a large public institution for his graduate degree. Ron is a self-described "student government kid," and served as SBP at the end of his college career. Ron now works professionally in student activities at a small private institution.

Serge is from the Western part of the United States and went to school in the Mid-Atlantic. He served as SBP during his fifth year of school. Serge took two years between graduation and starting graduate school to work as an education consultant. While he is not pursuing a HE/SA degree, his assistantship is working in student activities.

\section{FINDINGS: STUDENT GOVERNMENT AS STUDENT AFFAIRS PRACTICE}

For participants, there was a suspension of self when getting involved in student government. By and large, their college experiences were defined by their student government work. Some even share that student government changed their life. Others share that it was their whole (undergraduate) life. As the interviews concluded, themes emerged. Between having a seat at the table, exposure to careers in HE/SA, and the (official) transition into the field beyond the undergraduate status, these individuals had been student affairs practitioners all along.

\section{A Reserved Seat at the Table}

Resoundingly, former SBPs knew "the table" and had a frequently reserved seat. In fact, they had many seats. The "table," in this context, was a space for students-namely SBPs-on committees, and with access to university administrators. Penny asked:

Who's actually sitting at the table? And what tables are they sitting at? Yeah, cool, I can be sitting at a table, I could be invited to a committee. But am I invited to the Homecoming planning committee, or am I invited to hiring our new Dean?

Between the participants, seats taken included committees for major administrator position vacancies, policy updates, residence hall development, Faculty Senate and Board of Trustee meetings, and with votes toward major financial and structural decisions.

Karlie viewed this work as "getting that first look behind the curtain." This meant having access to information before others in the community. For example, before the rollout of a major strategic plan, Gus met with the president of his institution and provided feedback on behalf of the students. Serge was also privy to information in advance and would often learn about campus happenings before the rest of the community. Karlie, Adam, and Ron were all non-voting members on their institution's Board of Trustees, and Adam held a seat on the president's advisory council. While Karlie felt it was more about the look of having students present, she was serious about speaking up and representing the student body. Abigail felt similarly that there was a "placeholder" feel on some of her committees.

These seats were inherited and came with the territory of being SBP. This was not always a space that was welcoming of students. Abigail recalled having a spot and vote on a major university budget committee but felt at times that she did not know what was going on and had to meet one-on-one outside of those meetings to gain the full picture. While she felt a responsibility to advocate for students, sometimes the full picture revealed more dismal options. Abigail shared, "I'm here as a student saying, 'You probably shouldn't up tuition, and then I'm like, 'Oh, we're getting our budget slashed in half."' 
This theme also manifested as a seat at the table with administrative one-on-one access. Adam shared, "Once you're connected with the staff and administration, you're connected throughout campus." Here, SBPs had direct and frequent engagement with administrators, and experienced relationships that were not the norm for other students on their campus. Gus met with the Provost and Dean of Students weekly and with the president every three weeks. "No other student had that access," he shared. Gus considered the Dean of Students a close friend and mentor, and Adam shared, "If I needed anything, they were always there." Ron recalled meeting weekly with the Dean of Students and student government advisor. He found these individuals there for him in advising capacities and felt that they got to know him as a human. Abigail felt similarly. When there were significant sexist remarks made in a student government meeting, a senior student affairs officer invited all the women in the Senate to her home to have a more in-depth discussion about women in leadership. This impacted Abigail, who felt a deep connection to her student affairs administrators.

Adam saw drawbacks to this access. "It's not good for one student to have so much power," he shared, noting his struggle with the access granted to him. For many, the expectation that administrators saw them as allies was part of the access and power. For example, Abigail succeeded an SBP that did not have a relationship with administrators. She felt administrators were excited about her serving as president because she was not actively "fighting against them." Consequently, Ron never felt an adversarial role with administrators. However, this was at odds with his Vice President, who did not care for administrators. Additional drawbacks included outward-facing perceptions. Gus remembered having to defend administrator decisions to his peers, especially as he saw his Dean of Students advocate for students and student life in ways his peers did not always see and in ways other administrators dismissed. Karlie had a similar experience, as access and relationships between student government and administrators were tense at times. Some students viewed student government as "in the pocket" of the university administration. For example, when the university administration attempted to force the student government to allocate funds to a specific area without going through the allocation process, Karlie and her peers stood up to what felt like manipulation. "There were these ways that certain administrators would try to take advantage of that [relationship]," Karlie shared.

\section{Pre-Exposure to a Career in HE/SA}

It is undeniable that former SPBs had a unique and up-close view of HE/SA. The tackled issues alone were wide-reaching and deeply rooted in serving and services for students. Emily reflected on her early days as SBP, when she moved the campus conversation from "broken cups in the dining hall" to things like accessibility and security on campus, new residence halls, and funding issues, and language options for course credit. She also worked to expand Title IX and multicultural programs at her institution. Emily's institution treated her as a fulltime employee, and she shared, "I was the only student affairs staff person on our Provost search committee, and I was an undergraduate student. ... I represented the student voice and the student affairs voice." Similarly, Serge addressed performance spaces on campus, sustainability, a bike-share problem, and a university milestone program. Abigail accomplished a lot in her presidency, including addressing employee employees' wages, open-access textbooks, and several measures to hold the student Senate accountable.

Both Ron and Gus experienced issues with third-party conservative organizations. As his student government worked with student organization recognition, Ron dealt with conflict associated with one such organization, Turning Point, and "all hell broke loose." Understanding the bigger picture that student organizations should be recognized if they met the standards of registration, Ron saw the ways political entities interacted with(in) HE/ SA. Despite the personal dilemma, Ron exemplified a neutral approach to the matter. Gus dealt with a national free-speech group that impacted his time as SBP, which led to significant diversity and inclusion issues on his campus (ones that were veiled as free speech). He felt his administrators were not fully prepared for these issues, and the students became the leaders on that topic. As such, Gus developed a deeper understanding of free speech, something he thought he knew about, but that was further developed because of these incidents.

Even despite relationships, participants acknowledged the reality of some tensions within learning about HE/ SA. Ron shared: 
I also knew that I could sit in this student role, and I could be student body president and speak their language, but never lose sight of sort of who I was and what I was advocating for, and what my positionality was, and there was power in that. I didn't need to become them in order to interact with them.

Over time, Ron understood the importance of environment and voice and access and opportunity to and for students and the community. In many ways, Ron was a "[SBP] for the people." He was bringing things to campus that, on some campuses, were done by full-time HE/SA practitioners. Karlie experienced similar responsibilities and noticed that students were expected to do work in place of having staffing or full-time positions geared toward some of the areas claimed as institutional values (e.g., a full-time staff member doing diversity and inclusion work as opposed to students carrying the load). As SBP, Karlie created space for administrator-student interactions through forums and created a multicultural affairs programming team after the institution collapsed the full-time position. She also questioned why the institution was not funding sexual assault prevention programming, and publicly challenged her administrators to accommodate that need.

More importantly, the developed skills were those that were readily accessible and applicable to their practice. For example, in a class with his graduate school cohort, Gus recalled an example when a peer commented about higher education that he felt was inaccurate. He drew on being SBP to respond. At that moment, Gus realized many of his peers did not have this same frame of reference. In her finance coursework, Karlie knew how things worked in HE/SA, and this helped her provide examples related to her student government experience. In Penny's courses, she realized how advisors influenced her, even if she was not ready for that development at the time, and saw student development theories come to life in reflection of her experiences. Abigail appreciated her graduate program, and the scaffolding helped her think about social justice and identities prior to delving into student development theories. While she considered herself socially aware and social justice-minded, she realized that some of her language or approach as SBP at times deferred more to administrators than to students.

\section{Whiplash, in Transition}

Many participants felt a dissonance associated with their post-SBP transitions. The dissonance was startling, and some explained this as a type of whiplash, or a quick movement from "hot-to-cold." Ron reflected:

You have a place in the room... They're welcoming your voice. They see that you have power. You don't really need to build an ethos for yourself, it's sort of built-in. And that all went away when I became a grad student.

Penny remembered seeing her undergraduate president on campus with great visibility. In her first year of graduate school, she recalled seeing the president only three times. "He has no idea who I am, and he probably couldn't care less," she shared. Serge said the post-SBP transition was rough, and he went from being "that person" on campus, to being at the bottom of the organizational chart. This included moving to another state and not knowing anyone at his new company. Also working directly after graduation, pre-graduate school, Penny's post-SBP experience was mixed. She found it difficult to redefine herself after serving as SBP and navigating life no longer as a student.

Gus felt like "a nobody" who went to class and only did school when he started his master's degree. It was even more difficult for him when he did not enjoy his graduate assistantship, and upon realizing he did not have the agency to make changes in that environment. As an undergraduate, Gus shared that he could make a quick meeting with the Dean of Students. "That was a privilege. It was a deep, downright, straight-up privilege to have that," he shared. Gus appreciated this learning, but it was hard as things did not change. As such, it became more about learning how to deal with the non-change.

The transition for some was also rooted in institution type. For Emily, levels of "being at the table" did not exist in her graduate assistantship as they did at her previous institution. The transition moved from an institution-centered approach as SBP to the department/student-focus as a practitioner. The size of her new institution was a struggle, and she experienced "culture shock." Going into her career, Penny understood the ins and outs of a small private institution, and she felt very prepared for this setup of higher education. She felt a disconnect when 
she got to her graduate institution.

Some were prepared for the challenges that existed following their presidency. Emily's mentor sat her down before starting graduate school and shared with her that there will be many people like her at her new institution - people who did great things, with a lot of institutional impact. Similarly, Ron's mentors challenged him to think about the transition in advance, and he aspired not to be seen as "the guy that acts like they're still in undergrad in grad school." He did not want his experience over the previous four years to serve as a benchmark for the years ahead. Ron worked on tempering his expectations when he got to his master's program, but there was still a struggle figuring out his new institution's dynamics. There were times when Ron would miss the engagement of student government, and he found himself to "perk up" about student government-related conversations with his cohort and in class. He ultimately decided that his graduate institution was so large, and being a graduate student; he just resolved to focus on learning and academic pursuits.

Others found a connection on their campus, just not to the institution at large. The participants who went immediately to a graduate school established a community and investment in their academic department or assistantship. While she prepared herself to be "no one" at her new institution, between her assistantship and the community she works with, Emily was given more of a voice than she realized. "I feel like, at times, I'm right back at the table, and even when I'm not at the table, I'm speaking through the door, and they're somehow listening," she shared. This feeling drew Emily to view her assistantship in a more positive light than how she viewed the institution at large.

While Serge found himself knowledgeable about the field, he questioned if he had the "qualifications" to be a practitioner (e.g., a master's degree or more work outside of his undergraduate experience). Similarly, Penny felt pressure as a new professional because she had developed such a competence for herself as an undergraduate student. Karlie's transition was tough. She felt going to her master's program was like going to college for the first time. She shared, "I was coming off of...knowing everyone, people knew me, knowing all the administrators...if I needed something, I knew where to find it." Karlie had a supportive student affairs staff at her undergraduate institution, but dealt with a very opposing environment in her graduate program. In the new environment, she dealt with a supervisor who cursed at her and disrespected her in different ways. She eventually developed a mentorship with another advisor who affirmed her work and presence.

\section{DISCUSSION AND INSIGHTS}

Rather than "implications" or "recommendations," I engage in the realm of phenomenology that suggests the offering of insights into what it means to work with or better understand this phenomenon (van Manen, 1997). Here, there are possible implications for working alongside this population of students and practitioners. This is done by reexamining the metaphor of a "seat" at "the table" through the lens of elections and representation, and illuminating a retirement-like feel expressed by former SBPs.

\section{If the "Seat" Matters, Elections Matter}

Over time, many of the participants questioned the seats they occupied at each of the tables they frequented as SBP. Each seat represents a set of values and might place value on whose voice is essential in higher education. But with their seats at the table, I wonder, what is it about the seat that prioritizes the position over the person? The reality is that the seat itself is not reserved for a particular student, and instead, it is saved for whoever occupies the position. Besides being elected (which is a significant accomplishment), there are no set criteria for many of the seats these SBPs occupied. It is the election itself that determines such reservation. Campus activities officers and student government advisors should consider how committees are designed and how students are representative. Having a healthy balance of elected-into, applied-for, and appointed-to seats may allow for representation to span beyond elected-only capacities.

The relatively low number of students who vote in student government elections is also a critical component to 
illuminate. Dungan and Klopf (1949) cited student body election vote percentages to run as low as $9 \%$ of any given student body. Seventy years later, the NCLC cites averages to be around 22\% of the student body (Student Voice Index, 2018). While the number has more than doubled, this is still a relatively low population of students who determine who gets to sit at the various tables of administrative power. Furthermore, some participants ran unopposed, which hints at this same reality. The position grants the seat. This also hints at the complexity of higher education work and that, at times, undergraduate students have more power than some institutional staff members. While the power is symbolic, it is also temporary (by the person). Such a system calls for an understanding that individuals working in HE/SA may share their job responsibilities with undergraduate students. Like the robust education often needed for campus activities professional positions, a similar or abridged training should be considered for students elected to student government roles (e.g., learning about college students, event management, organization budgets, meeting facilitation). First-year student government mentoring programs and internships for young or new students are ways to engage such training or education as preparation for elected roles.

I do not doubt that these participants were all worthy of such seats, but many shared realizations that questioned their access and if other students should have been afforded such spaces. For example, Serge only won his election by a handful of votes. Had a few students voted differently or not at all, a different student would have received the access that Serge was afforded. This is a reminder that the seats themselves are occupied by the position and not always student-specific. The winner gets the seat. Perhaps this is why organizations like Turning Point seek to engage with student government elections to infuse Conservative values into the position (no matter the person, it is the seat that adds benefit). Student affairs practitioners who advise or work with student government can develop pathways for elected leadership, including minoritized students and those who possess identities not typically represented in student government.

As many participants shared that the seats themselves were about the optics of student input, Abigail reiterated that it was also about social capital and a way for institutions to make it seem like the student voice mattered. When students serve on committees, there should be a deep reflection about how they are asked (or expected) to show up and in what ways they can influence and lead within spaces that are granted by position. HE/SA entities can be intentional, and still, there is a hierarchical observance that dominates much of the ways people are asked to show up and do decision-making work. Practitioners should consider engaging with a wide range of students to do committee work beyond those elected to the highest roles (e.g., committee representation, applied-for positions). This might allow a younger generation of leaders to experience this work to prepare for an elected student government experience. While much of the literature on leadership education has noted that a focus should be on leaders as made rather than born (Dugan, 2017), practitioners should think beyond the positional leadership narratives that have dominated HE/SA for quite some time.

\section{Student Leader Retirement}

At the end of their time in office, the former SBPs were tired. This feeling permeated through our conversations, and there was a feeling of doneness that was hard to ignore. To pack a platform worth of passion and goals into one's presidency is a significant task. Many of these former SBPs had been involved throughout their undergraduate journey, and some even engaged with student council and student government in middle school and high school. Emily framed the post-SBP experience as a sort of student leader "retirement." Her experience(s) in student government were valued deeply. Emily shared, "What the association represented to people and what it could do mattered more to me than anything. Like, this idea when I came in my freshman year of wanting to make a name for myself, that no longer mattered." Feelings such as these contributed to both the whiplash-like feeling of transition and the doneness associated with this kind of student leader retirement.

There is a transition within this retirement, and Penny shared, "It's like you feel like you've hit your peak. Great, you're Student Senate president, everyone loves you, and then you move on, and there's no going up from there." Now that she has left the institution, she feels differently, but her initial departure was difficult. This struggle was shared across the participants, and there was a bittersweetness for some. As new SBPs and student government officers take over in quick succession, attention should be made to the ways students depart their role as SBP and student leadership more broadly. Like an airplane beginning the descent for landing, such a retirement should 
be handled with care, especially for those going into HE/SA work post-graduation. Practitioners can focus on the "retirement" of outgoing student leaders and develop transition opportunities to help students exit their role.

Administrators and practitioners can address the retirement-like feel by exploring contributing factors that might lead students to feel that they are done. For example, examining committee start and end dates, election cycles, and duplicate representation (e.g., one person in multiple committees) may all be areas where transition and departure are most helpful to students. However, similar to some functional areas in student affairs, is there a burn-out that is hard to ignore related to the experience of an SBP? Here, there is a calling to think about what it means to be a "retired" student leader and be done with more than the role itself.

The participants in this study took their student government responsibilities seriously and operated as if they were working for their institution all along. For some, this meant feeling like they were "on" and available at all times. To experience work in this to-be-accessible kind of way, at times, participants described themselves as separate from their peers - that, to do this work, they already saw themselves as practitioners, despite the pre-career view (pre-exposure), and despite the transition (whiplash). Campus activities practitioners and student government advisors can be attentive to this whiplash-like feel by preparing students for entering and exiting the role. In the case of actual whiplash, where the stress and pain manifest in the bodily form (aching neck, shoulders), advisors can anticipate how to best support students with this reality in mind (e.g., how physical therapy may be beneficial in the case of actual whiplash). Practitioners can encourage students to seek therapy or counseling, plan for their transition, seek community opportunities that mirror a student government leadership experience, and more.

\section{Opportunities for Future Research and Exploration}

Finally, questions remain as I journey from this initial exploration of former SBPs working in HE/SA. But these questions involve a broader examination of student affairs and the functions at play regarding student government and students' governance. For example, for those who had fraternity/sorority life at their institutions, "the Greek vote" became a contentious topic regarding elections. Penny shares, "When we're talking about fraternities and sororities coming together and voting for people, it becomes very gendered, and it becomes very much like, 'Well we're going to vote for our boy." Karlie believed it was a privilege to be in a sorority and that it wielded power, money, and social capital. The vote- and support-lines are drawn based on membership and are not necessarily about work or capability. Issues like organizational support and voting blocs may be a future exploration associated with the phenomenon of student government and leadership. The fraternity/sorority privilege associated with student government cannot be ignored and should be interrogated in future research.

Next, there are gender dynamics that should be addressed in future student government research. Rupert Davis (2019) suggests that campus administrators and community members should be apprised of bias and stereotypes faced by women student leaders. All of the women in this study talked about the different ways women were treated in leadership. Emily was told she needed to have a "softer" approach and was called "bitchy" and "aggressive" as compared to former (male) SBPs. At Penny's institution, student government was very gendered and male-dominated, and she felt like it was not necessarily "she can't because she's a woman," but more so, "he can because he's a man." Karlie ran against a fraternity man for president. This was the first time she felt gender at play, as some people voted for her opponent solely because he was a man (and without care that she was the most experienced student government representative at the time). Future research can directly consider the way gender shows up in student government spaces, including students' experience and the responsibility of advisors. Like Abigail's administrator who invited the women of student government to her home, other studies about the intersection of gender and student government should occur in both the personal and professional context. The act of inviting the women in student government into an "affinity" space for women, as a start, is a promising practice for campus activities practitioners and student government advisors. 


\section{PRACTITIONERS ALL ALONG}

These past SBPs working in HE/SA had access to administrators and campus decision-making through the seats afforded to them due to their presidency. They had exposure to HE/SA as a possible career. And they experienced a jolting transition from their undergraduate to postgraduate work experience(s). As SBP(s), these individuals were student affairs practitioners all along, doing the work with and alongside full-time HE/SA practitioners, and engaged at some of the highest levels among their undergraduate peers.

Coming back to my own experience as SBP, the privilege of texting my university president on graduation morning is not lost on me. The privilege of being elected to (powerful) seats and eventually "retire" is not lost. To better understand this population and phenomenon, such experiences are necessary to illuminate. While few people achieve the role of SBP, this study can add to what we know about students entering the field of HE/SA already with such a bountiful connection to the profession.

\section{REFERENCES}

American Student Government Association. (n. d.). "Why is SG Important?” Retrieved from: https://asgahome.com/why-is-sg-important/

Alexander, W. M. (1969). Rethinking student government for larger universities. The Journal of Higher Education, 40(1), 39-46.

Arminio, J. L., \& Hultgren, F. H. (2002). Breaking out of the shadow: The question of criteria in qualitative research. Journal of College Student Development, 43, 446-460.

Bevan, M. T. A method of phenomenological interviewing. Qualitative Health Research, 24(1), $\quad$ 136-144.

Bloland, P. A. (1961). A new concept in student government. The Journal of Higher Education, 32(2), 94-97.

Collins, D. (2009). The socialization process for new professionals. In A. Tull, J. B. Hirt, \& S. A. Saunders (Eds.), Becoming socialized in student affairs administration: A guide for new professionals and their supervisors (pp. 3-27). Stylus.

Dugan, J. P. (2017). Leadership theory: Cultivating critical perspectives. Jossey-Bass.

Dungan, Jr., R. A., \& Klopf, G. (1949). Student leadership and government in higher education (revised). United States National Student Association.

Frederick, R. W. (1965). Student activities in American education. The Center for Applied Research in Education, Inc.

Gadamer, H-G. (1975). Truth and method. Continuum.

Golden, D. C., \& Schwartz, H. L. (1994). Building an ethical and effective relationship with student government leaders. In M.C. Terrell \& M. J. Cuyjet (Eds.), New Directors for Student Services: No. 66. Developing student government leadership (pp. 19-30). Jossey-Bass Publishers.

Hall, M. R. 2014). Job one 2.0: The next generation. In P. M. Magolda \& J. E. Carnaghi (Eds.), Job one 2.0: Understanding the next generation of student affairs professionals (pp. 1-10). University Press of America, Inc.

Hultgren, F. H. (1995). The phenomenology of "doing" phenomenology: The experience of teaching and learning together. Human Studies, 18, 371-388.

The JBHE Foundation, Inc. (1998). Compensation for student government leaders at HBCUs. The Journal of Blacks in Higher Education, 20, 39.

Klopf, G. (1960). College student government. Harper \& Brothers.

Komives, S. R. (2019). Engagement with campus activities matters: Toward a new era of educationally purposeful activities. Journal of Campus Activities Practice and Scholarship, 1(1), 14-25.

Kuh, G. D., \& Lund, J. P. (1994). What students gain from participating in student government. In M.C. Terrell \& M. J. Cuyjet (Eds.), New Directors for Student Services: No. 66. Developing student government leadership (pp. 5-17). Jossey-Bass Publishers. 
Kuk, L., \& Cuyjet, M. J. (2009). Graduate preparation programs: The first step in socialization. In A. Tull, J. B. Hirt, \& S. A. Saunders (Eds.), Becoming socialized in student affairs administration: A guide for new professionals and their supervisors (pp. 89-108). Stylus.

May, W. P. (2010). The history of student governance in higher education. The College Student Affairs Journal, 28(2), 207-220.

Miles, J. M. (2011). Reflections of student government association leaders: Implications for advisors. College Student Journal, 45(2), 324-332.

Miles, J. M., Miller, M. T., \& Nadler, D. P. (2008). Student governance: Toward effectiveness and the ideal. College Student Journal, 42(4), 1061-1069.

Miller, C. D., \& Kraus, M. (2004). Participating but not leading: Women's under-representation in student government leadership positions. College Student Journal, 38(3), 423-427.

Mink Salas, K. (2010). Aspiring to leadership: Factors that impede and encourage college women in running for the student body presidency (Unpublished doctoral dissertation). The Claremont Colleges, Claremont, CA.

Patton, M. (2002). Qualitative research and evaluation methods (3rd Ed.). SAGE Publications.

Racial Attitudes of America's Youth. (2000). The first Black student body president at Ole Miss. The Journal of Blacks in Higher Education, 27, 13.

Renn, K. A., \& Hodges, J. P. (2007). The first year on the job: Experiences of new professionals in student affairs. Journal of Student Affairs Research and Practice, 44, 604-628.

Rupert Davis, K. (2019). Shattering the collegiate glass ceiling: Understanding the experiences of women student government presidents. (Unpublished doctoral dissertation). University of Maryland, College Park, MD.

Smith, E. A., Miller, M. T., \& Nadler, D. P. (2016). Does it matter? What college student governments talk about. Journal of Higher Education Theory and Practice, 16(2), 46-53.

Spencer, G. L. (2004). A qualitative analysis of female student body presidents (Unpublished doctoral dissertation). Kansas State University, Manhattan, KS.

Student Voice Index. (2018). National Campus Leadership Council. Retrieved from: https://www.studentvoiceindex.org/

Terrell, M. C., \& Cuyjet, M. J. (1994). Editors' notes. In M.C. Terrell \& M. J. Cuyjet (Eds.), New Directors for Student Services: No. 66. Developing student government leadership (pp. 1-3). Jossey-Bass Publishers.

Tull, A., Hirt, J. B., \& Saunders, S. A. (2009). Becoming socialized in student affairs administration: A guide for new professionals and their supervisors. Stylus.

Van Manen, M. (1997). Researching lived experience: Human science for an action sensitive pedagogy (2nd Ed.). The Althouse Press.

Van Manen, M. (2014). Phenomenology of practice. Left Coast Press.

Workman, J. L., Hull, K., Hartsell, T., \& Weimann, T. (2020). A chilly climate: Experiences of women student government association presidents. The Journal of Campus Activities Practice and Scholarship, 2(2), 39-54.

Zimmerman, H. (2017). Navigating the labyrinth toward college student government presidency: A phenomenological study of women who run for student government president (Unpublished doctoral dissertation). University of California, Los Angeles, Los Angeles, CA. 